\title{
Genetic evaluation of a proposed introduction: the case of the greater prairie chicken and the extinct heath hen
}

\author{
ERIC P. PALKOVACS,${ }^{*}$ ADAM J. OPPENHEIMER,${ }^{*}$ EUGENE GLADYSHEV, †OHN E. TOEPFER, \\ GEORGE AMATO,§THOMAS CHASE II and ADALGISA CACCONE*** \\ *Department of Ecology and Evolutionary Biology, + School of Forestry and Environmental Studies and ${ }^{* *}$ Molecular Systematics and \\ Conservation Genetics Laboratory, Yale Institute for Biospheric Studies, Yale University, 165 Prospect Street, New Haven, CT 06520 , \\ USA, †Society of Tympanuchus Cupido Pinnatus, Plover, WI 54467, USA, §Wildlife Conservation Society, Bronx Park, NY 10460, \\ USA, IThe Nature Conservancy, Vineyard Haven, MA 02568, USA
}

\begin{abstract}
Population introduction is an important tool for ecosystem restoration. However, before introductions should be conducted, it is important to evaluate the genetic, phenotypic and ecological suitability of possible replacement populations. Careful genetic analysis is particularly important if it is suspected that the extirpated population was unique or genetically divergent. On the island of Martha's Vineyard, Massachusetts, the introduction of greater prairie chickens (Tympanuchus cupido pinnatus) to replace the extinct heath hen (T. cupido cupido) is being considered as part of an ecosystem restoration project. Martha's Vineyard was home to the last remaining heath hen population until its extinction in 1932. We conducted this study to aid in determining the suitability of greater prairie chickens as a possible replacement for the heath hen. We examined mitochondrial control region sequences from extant populations of all prairie grouse species (Tympanuchus) and from museum skin heath hen specimens. Our data suggest that the Martha's Vineyard heath hen population represents a divergent mitochondrial lineage. This result is attributable either to a long period of geographical isolation from other prairie grouse populations or to a population bottleneck resulting from human disturbance. The mtDNA diagnosability of the heath hen contrasts with the network of mtDNA haplotypes of other prairie grouse (T. cupido attwateri, T. pallidicinctus and T. phasianellus), which do not form distinguishable mtDNA groupings. Our findings suggest that the Martha's Vineyard heath hen was more genetically isolated than are current populations of prairie grouse and place the emphasis for future research on examining prairie grouse adaptations to different habitat types to assess ecological exchangeability between heath hens and greater prairie chickens.
\end{abstract}

Keywords: ancient DNA, conservation genetics, heath hen, mtDNA, population introduction, Tympanuchus

Received 27 November 2003; revision received 13 February 2004; accepted 13 February 2004

\section{Introduction}

An emerging goal of conservation biology is to restore degraded ecosystems. When local extirpation has removed a species from an ecosystem, population introduction may be a useful tool for ecological restoration. Such a strategy would be applicable only after careful analysis revealing that the original causes of the extirpation could be

Correspondence: Eric P. Palkovacs. Fax: + 1203 4327394; E-mail: eric.palkovacs@yale.edu ameliorated and that natural recolonization is unlikely. The World Conservation Union (IUCN) states that, for introduction projects, individuals should be taken from the same subspecies as those extirpated (IUCN 1995); however, this may not be possible in cases where entire subspecies have become extinct. In such cases, efforts must be made to evaluate the suitability of possible replacement populations. Such efforts should consider the genetic relatedness, phenotypic and ecological similarity and conservation value of introduction candidates (Seddon \& Soorae 1999). In this study, we use mitochondrial 
DNA (mtDNA) sequences to examine genetic divergence between the extinct heath hen (Tympanuchus cupido cupido) and extant populations of greater prairie chickens (T.c. pinnatus) to help determine whether the greater prairie chicken represents a suitable substitute for introduction.

The decline of the heath hen began when the first Europeans arrived on the East Coast of North America. Before European settlement, Native Americans used fire to maintain a mosaic of forests, shrublands, agricultural fields and grasslands (Pyne 1982). After European diseases decimated Native American populations, the formerly open habitats of the Northeast became largely forested, resulting in major changes to bird communities (Droge 1998) and probably reducing suitable heath hen habitat. Although the clearing of forests by European settlers probably once again increased heath hen habitat, hunting pressure was extreme, and by 1821 the formerly common bird was rare in New England (Forbush 1927). The last reports of heath hens in Pennsylvania and New Jersey are from 1869, and it is doubtful that the heath hen survived much after that on mainland North America (Forbush 1927). After that time, it was restricted to the island of Martha's Vineyard, Massachusetts. On this island, the heath hen's doomed struggle against extinction played out. After a fire in 1906 reduced the population to approximately 80 individuals, the Massachusetts Legislature created a refuge for the remaining birds. Extensive efforts to preserve the heath hen included a failed reintroduction to Long Island, attempted predator eradication, fire control and the planting of cultivated crops for dietary supplementation (Gross 1928). On Martha's Vineyard it appeared that these efforts were paying off, as E. H. Forebush counted 800 heath hens on the refuge in April 1916 and estimated that there were 2000 heath hens living on the island (Forbush 1927). However, on 12 May 1916 a massive fire broke out on Martha's Vineyard, burning nearly $20 \%$ of the island during nesting season and devastating the heath hen population. The fire was followed by heavy raptor predation the following year and the suspected eruption of a poultry disease, all of which contributed to the ultimate decline of the heath hen (Gross 1928). The world's last heath hen, affectionately nicknamed 'Booming Ben', died in 1932, having been the lone survivor of his kind for nearly 4 years (Cokinos 2000). Detailed descriptions of the events leading to the extinction of the heath hen are given in Gross (1928) and Cokinos (2000)

Because the heath hen did not gain the attention of ornithologists and museum collectors until after the mainland population had been extirpated, there is uncertainty regarding the extent of the heath hen's original geographical range and the scope of its morphological variation. The portion of the heath hen's range from Virginia north into New England (depicted in Fig. 1) is well documented. However, Brewster (1885) and Gross (1928) speculate that the heath hen may once have roamed as far south as the Carolinas and as far west as western Pennsylvania, eastern Ohio and Kentucky, possibly contacting populations of Midwestern greater prairie chickens, although the information supporting this view is sparse.

Because no mainland heath hens appear to have been preserved in museum collections (Gross 1928), the scope of the morphological variation of the heath hen throughout its original range will never be known. W. Brewster's original description in 1885, based solely on birds from Martha's Vineyard, highlights the morphological differences between heath hens and Midwestern greater prairie chickens. Heath hens were smaller in size and had shorter tarsi than greater prairie chickens. Their neck tufts contained four to five rather than seven to 10 pinnae (rigid neck feathers erected during courtship displays), which were narrower and acutely rather than obtusely lance-pointed, and the heath hen's plumage was more red above and more white below than that of the Midwestern greater prairie chicken (Brewster 1885). However, in a subsequent study A. O. Gross noted his difficulty in telling the two subspecies apart based on external morphological differences (Gross 1928).

In addition to the heath hen, the other prairie grouse of the genus Tympanuchus have been negatively impacted by human activity, and their ranges have been greatly reduced since historical times (Fig. 1). The Attwater's prairie chicken (T.c. attwateri), which once occurred along the Gulf Coast of Texas and Louisiana, declined as a result of agriculture and urban development and is now restricted to two small populations in Texas. These populations are persisting largely as a result of supplementation from captive-bred birds and, at fewer than 70 individuals, face the pending threat of extinction (Silvy et al. 1999). The greater prairie chicken, which occupied the tallgrass prairies of the Midwestern United States, has declined substantially as cropland has gradually replaced native grasslands (Svedarsky et al. 2000). The lesser prairie chicken (T. pallidicinctus) of the southern Great Plains of the United States has declined more than $90 \%$ from historic levels due to the decline and fragmentation of native vegetative communities (Fuhlendorf et al. 2002). Similarly, agriculture has taken a toll on sharptailed grouse (T. phasianellus) populations in the United States (Johnsgard 1983).

Headed by the Nature Conservancy and local conservation groups, efforts to restore native vegetation and a natural fire regime on Martha's Vineyard are under way. These efforts carefully consider the appropriate vegetation to restore. Palaeoecological research indicates that prairie-like grasslands were not a major component of the Martha's Vineyard landscape at the time of European settlement (Foster \& Motzkin 1999; Motzkin \& Foster 2002). Instead, open oak shrub and ericaceous communities may have dominated. According to Gross (1928), this type of heathland, dominated by scrub oak (Quercus ilicifolia) and 
(A)

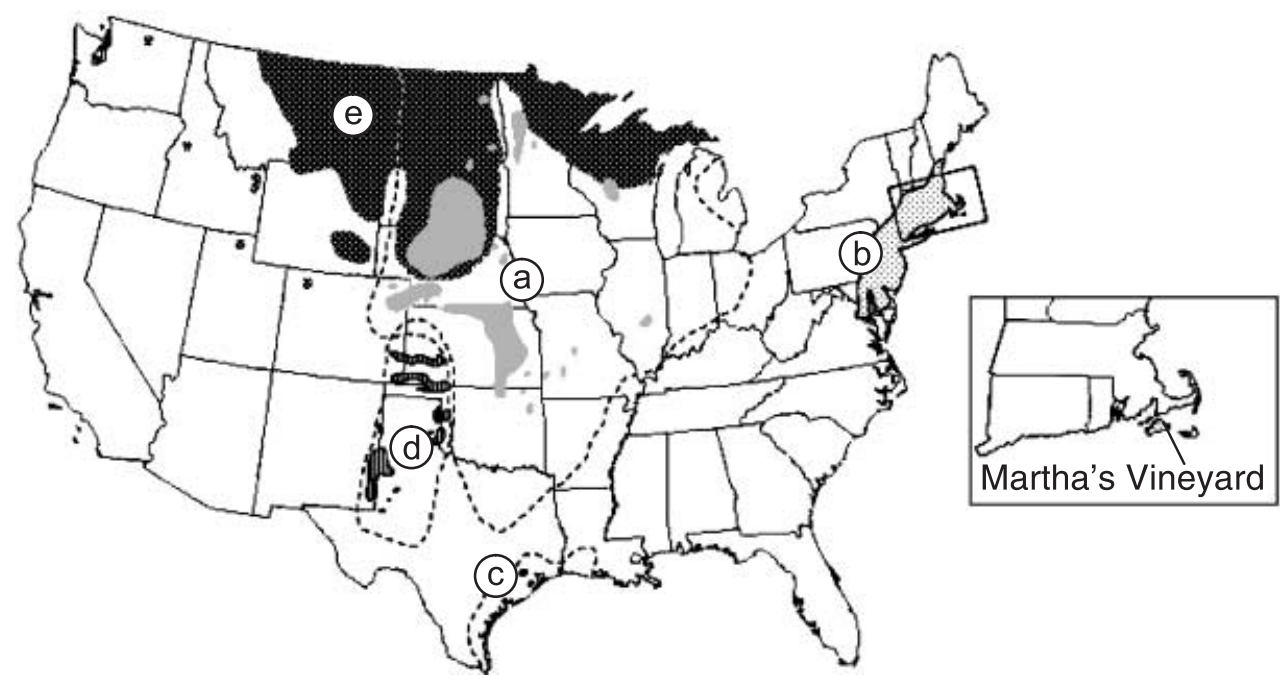

Sharp-tailed grouse

Greater prairie chicken

Heath hen

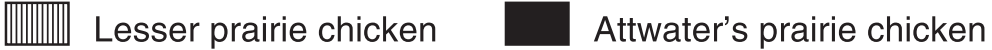

(B)

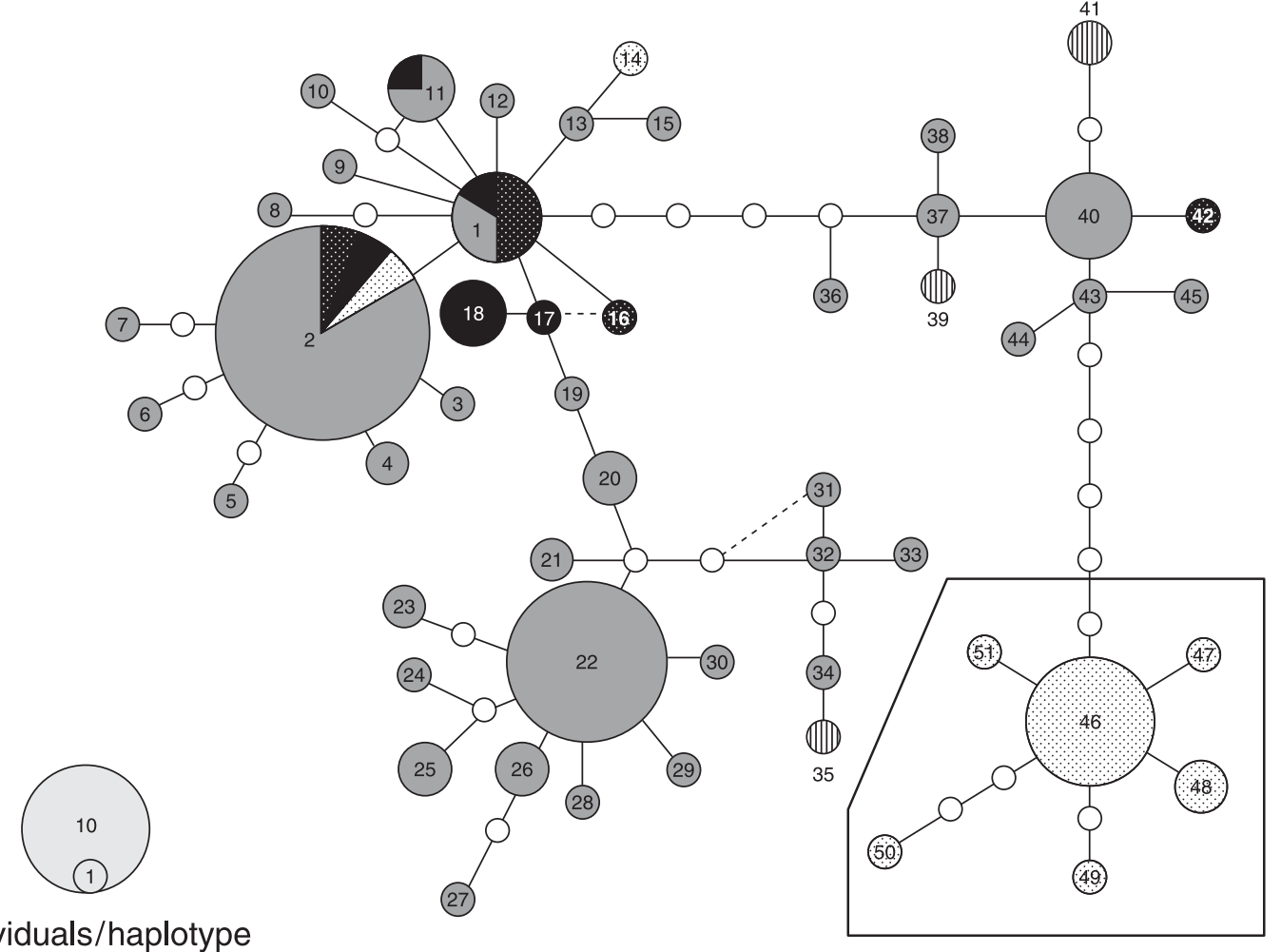

Fig. 1 (A) Map of current and historical ranges of Tympanuchus taxa. Ranges for (a) the greater prairie chicken, (b) the heath hen, (c) the Attwater's prairie chicken, (d) the lesser prairie chicken, and (e) the sharp-tailed grouse are depicted, with historical ranges outlined. The heath hen was extirpated from the mainland about 1870 and survived on the island of Martha's Vineyard until going extinct in 1932. (B) The haplotype network is derived from 480-bp of the mtDNA control region. The relative sizes of the circles represent the number of individuals contained within each haplotype (see legend, bottom left), and pie slices represent the fraction of each taxon contained within each haplotype. The shading in the network corresponds to that in the range map, with the greater prairie chicken in gray, the heath hen lightly stippled, the Attwater's prairie chicken in solid black, the lesser prairie chicken vertically striped, and the sharp-tailed grouse darkly stippled. Open circles represent missing haplotypes and dashed lines indicate that multiple connections between haplotypes are possible, but not favored. Haplotypes 46-51, contained within the bottom right polygon, are reliable heath hen haplotypes. Haplotypes 2 and 14 contain samples originally thought to be from heath hens, but which lacked collection information and may instead represent greater prairie chickens (see text). 
huckleberry (Gaylussacia baccata), was typical of that used by the heath hens of Martha's Vineyard. Living in this semi-open habitat, the heath hen was a generalist forager on both native and non-native species. Gross (1928) reports of the heath hen opportunistically taking fresh shoots in the spring, insects, leaves (especially Rumex acetosella) and various fruits (Myrica carolinensis, Arctostaphylos wa-ursi, Berberis vulgaris, Mitchella repens, Vaccinium spp., Rosa spp.) during summer, and acorns year-round. Research by the Nature Conservancy and the Ecosystems Center of the Marine Biological Laboratory are ongoing to identify the structure, species composition and means of restoration of native heathland habitat.

This study was conducted to assess the genetic distinctness of the extinct heath hen and to provide insights on the biological options associated with reintroducing a population of greater prairie chickens as an ecological equivalent to Martha's Vineyard. As the heath hen was probably the most area-sensitive species on Martha's Vineyard, restoring sufficient habitat to support an introduced population of greater prairie chickens would serve the purpose of protecting many other populations of rare plants, avifauna and invertebrates of the heathlands.

\section{Materials and methods}

Our analysis includes a total of 117 Tympanuchus individuals, including 18 heath hens, eight Attwater's prairie chickens, 80 greater prairie chickens, four lesser prairie chickens and seven sharp-tailed grouse (Appendix I). No mainland heath hen specimens appear to exist in museum collections (Gross 1928). Therefore, all the heath hen specimens (with collection information) examined in this study were collected on Martha's Vineyard after the mainland population had been extirpated. Five specimens sampled from museum collections on Martha's Vineyard (MV1, MV2, MV3, MV4, MV5, see Appendix I) originated in private collections, and thus lacked detailed collection information. Total genomic DNA was extracted either from museum skin tissue samples (heath hens) or from blood samples. For heath hen museum skins, a small $\left(1 \mathrm{~mm}^{2}\right)$ piece of tissue was cut from the pad of one toe using a sterile scalpel blade. DNA was extracted using the DNEasy Tissue Kit and Tissue Protocol (Qiagen), slightly modified to reduce the likelihood of contamination and to increase yield (see Mundy et al. 1997). To further avoid contamination, all museum skin extractions were performed in a room separated from the main laboratory and designated for ancient DNA, and negative extraction controls were carried out. Extractions from modern blood samples were performed using the Easy DNA Kit (Invitrogen) and the standard manufacturer's protocol.

Primers for the polymerase chain reaction (PCR) of the entire mtDNA control region (CR) were designed initially from the ND6 and tRNA-Phe genes of the domestic chicken (Gallus gallus) mitochondrial genome (Desjardins \& Morais 1990). PCR amplification and sequencing of the entire 1148 base pair (bp) CR in a randomly chosen group of 20 greater and Attwater's prairie chickens revealed most of the variation to be in the first $500 \mathrm{bp}$ of the $\mathrm{CR}$, adjacent to the tRNA-Glu. This region corresponds to domain I and is typically highly variable in birds (Baker \& Marshall 1997). Primers were designed to PCR and sequence this variable region. Primers EXT-DLFor (5'-GACTAATCCCAAGGACTACG-3') and INT-DL1Rev (5'-TGACTTCGTGAAAAGTGAGG-3') were used to amplify a $540 \mathrm{bp}$ fragment from all modern samples. PCR amplification was performed in a Touchdown Thermocycler (Hybaid) using $50 \mu \mathrm{L}$ reactions containing $1 \mu \mathrm{L}$ genomic DNA, 10 mm Tris-HCL ( $\mathrm{pH} 8.3$ ), $50 \mathrm{~mm} \mathrm{KCl}$, $1.5 \mathrm{~mm} \mathrm{MgCl}, 0.8 \mathrm{~mm}$ DNTPs, $0.4 \mu \mathrm{M}$ of each primer and 1.5 units of Amplitaq (Applied Biosystems). Each PCR run consisted of an initial 2-min denaturation step at $94{ }^{\circ} \mathrm{C}$, followed by 35 cycles of $1 \mathrm{~min}$ at $94{ }^{\circ} \mathrm{C}, 1 \mathrm{~min}$ at $56^{\circ} \mathrm{C}$ and $1 \mathrm{~min}$ at $72{ }^{\circ} \mathrm{C}$. PCR runs were concluded with a 5 -min extension step at $72{ }^{\circ} \mathrm{C}$. Negative PCR controls were run with each round of PCR.

Due to the degraded nature of DNA obtained from museum skin material (Cooper 1994; Landweber 1999), we were unable to amplify the entire $540 \mathrm{bp}$ fragment from museum skin samples. Therefore, we designed additional primers to amplify shorter fragments: HH2For (5'-TGTAATCGGACATAAAACCT-3'), HH2Rev (5'-AGGTTTTATGTCCGATTACA3'), HH4For (5'-CCCATTTGGTTATGCTCGAC-3') and HH4Rev (5'-GTCGAGCATAACCAAATGGG-3'). Primer pairs EXT-DLFor and HH2Rev, HH2For and HH4Rev, and HH4For and INT-DL1Rev each amplify about $200 \mathrm{bp}$ fragments, together spanning the entire region amplified in all modern samples. PCR reagents were as above with the addition of $0.01 \mathrm{mg}$ BSA and the use of Amplitaq Gold (Applied Biosystems). Museum skin PCRs were run on a Robocycler Gradient 96 Temperature Cycler (Stratagene), with runs consisting of an initial 12 min denaturation step at $94{ }^{\circ} \mathrm{C}$, followed by 40 cycles of $1 \mathrm{~min}$ at $94{ }^{\circ} \mathrm{C}, 1 \mathrm{~min}$ at $52{ }^{\circ} \mathrm{C}$ and $2 \mathrm{~min}$ at $72{ }^{\circ} \mathrm{C}$, and concluded with a 5 -min extension step at $72{ }^{\circ} \mathrm{C}$. Negative PCR controls and negative extraction controls were run with each round of PCR. To help minimize the risk of contamination, we performed PCR reactions for a subset of museum skin samples in a previously unused laboratory facility in a different building from the main laboratory. Of 39 total museum skin extractions performed, 18 samples successfully yielded PCR products.

For all samples, electrophoresis of $5 \mu \mathrm{L}$ of PCR products on $1 \%$ agarose gels stained with ethidium bromide was used to check for size and concentration. PCR fragments were cleaned using the Geneclean Kit (Bio101) and sequenced in both directions on an ABI Prism 377 automated DNA sequencer using BIGDYE TERMINATOR CYCLE SEQUENCING version 2.0 (Perkin Elmer). PCR products were sequenced 
directly only if visualization on an agarose gel revealed high-intensity bands. Museum skin PCR products were sequenced directly and not cloned due to the potential risk of introducing artefacts through cloning.

Sequences were edited using SEQUENCHER 5.0 (Gene Codes Corp.) and aligned using CLUSTALX 1.18 (Thompson et al. 1997). At the $5^{\prime}$ end of the alignment, sequences were trimmed to begin at the first nucleotide of the CR. At the $3^{\prime}$ end of the alignment, sequences were trimmed to minimize the impact of missing data. Therefore, $480 \mathrm{bp}$ of sequence data were analysed. Sequences were deposited in GenBank (Accession nos AY526753-AY526860). A haplotype network was constructed using TCs 1.13 (Clement et al. 2000). To be conservative about designating haplotypes, gaps were treated as missing data. When multiple connections to any haplotype were indicated, predictions from coalescent theory were used to choose the most probable alternative (Crandall \& Templeton 1993; Posada \& Crandall 2001). A haplotype tree was constructed using a starting tree obtained by the neighbour-joining (NJ) method (Saitou \& Nei 1987) implemented in PAUP* $4.0 \mathrm{~b} 10$ (Swofford 2000). MODELTEST 3.06 (Posada \& Crandall 1998) was used to determine the most appropriate model of sequence evolution (HKY $85+\Gamma+\mathrm{I})$ and to estimate the gamma parameter (0.5604) and the proportion of invariable sites (0.5674). The $\mathrm{NJ}$ tree was subjected to branch swapping using the branch and bound algorithm, and trees were evaluated under the likelihood model described above. Statistical support for nodes was obtained from 1000 bootstrap replicates. In addition, a Bayesian phylogenetic analysis of haplotypes was performed using the likelihood model described above. MRBAYES 3 (Huelsenbeck \& Ronquist 2001) was used to run 2000000 generations with a sampling frequency of 100 generations. The first 1000 trees were discarded to ensure that a stable likelihood had been reached. Bayesian support values were determined by calculating the percentage of trees found that contained that grouping. A phylogenetic analysis of grouse (Tetraoninae) by Drovetski (2002) provides evidence that Dendragopus obscurus is the sister group of Tympanuchus. Therefore, haplotype trees were rooted with two D. obscurus sequences. ARLEQUIN version 2 (Schneider et al. 2000) was used to estimate the haplotype diversity ( $h$, the probability that two randomly chosen haplotypes are different), the mean number of pairwise differences between all pairs of haplotypes $(\pi)$, and the nucleotide diversity $\left(\pi_{n^{\prime}}\right.$ the probability that two randomly chosen homologous nucleotides are different) for each taxon and population. The Tamura $\&$ Nei (1993) distance correction was used to calculate $\pi$ and $\pi_{n^{*}}$

\section{Results}

The haplotype network based on $480 \mathrm{bp}$ of the mtDNA control region is shown in Fig. 1. Haplotype 1 is the ancestral haplotype in the sample. Little structuring by taxon is revealed by this network, with the exception of heath hen samples which, except for two samples, are all contained within the polygon in the bottom right corner of Fig. 1 (haplotypes 46-51). This group of heath hen haplotypes are all at least six mutational steps from the nearest greater prairie chicken haplotype (43). The greater prairie chicken haplotypes nearest to the heath hen group are all from Wisconsin (haplotypes 40, 43, 44, 45). However, Wisconsin samples are also contained within haplotypes scattered throughout the network (haplotypes 2, 4, 22, 26, 27). Attwater's prairie chicken samples are contained within multiple haplotypes $(1,2,11,17,18)$ and do not form a distinct grouping. Similarly, lesser prairie chicken and sharptailed grouse samples are scattered throughout the network. In the phylogenetic reconstruction of haplotypes, $\mathrm{NJ}$ and Bayesian methods resulted in highly congruent topologies. No clades were well supported except the heath hen clade (haplotypes 46-51), which had a 96\% bootstrap value and a 100\% Bayesian support value (Fig. 2).

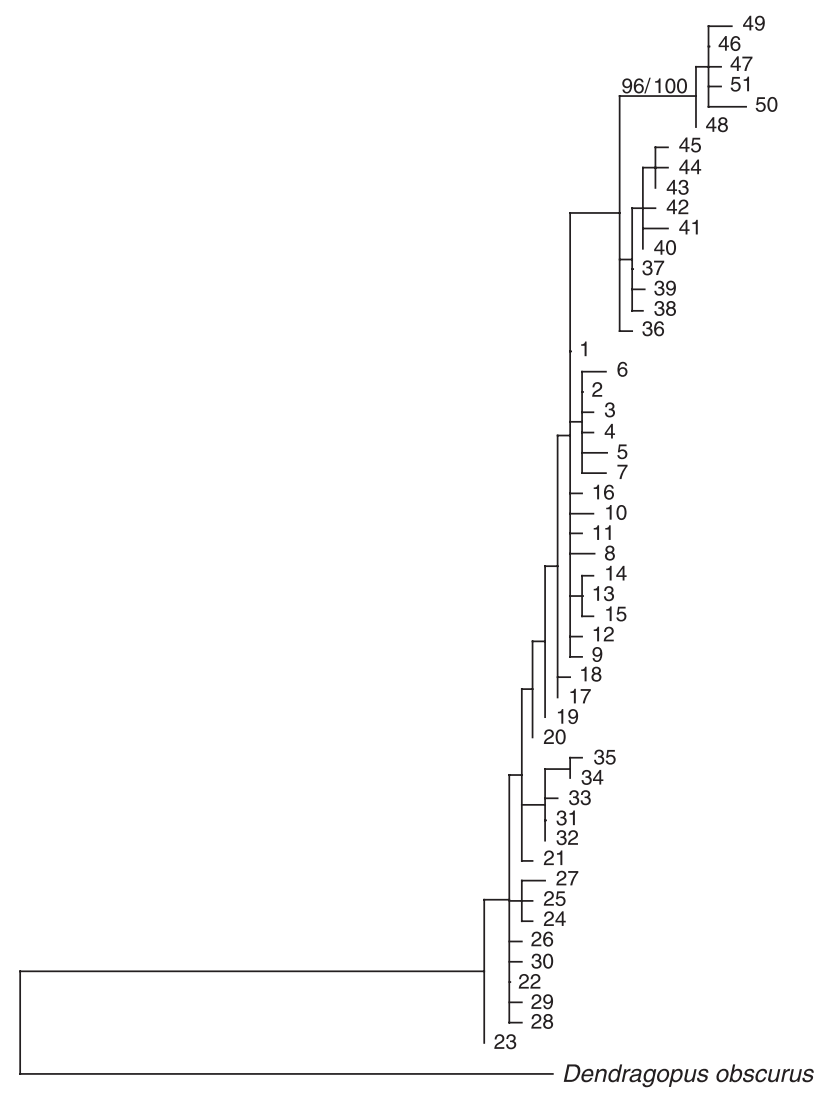

- 0.005 substitutions/site

Fig. 2 Haplotype tree obtained by the NJ method and subjected to branch swapping and evaluation under the HKY85 + $\Gamma+\mathrm{I}$ likelihood model. The lengths of the branches are proportional to the amount of genetic change. The only well-supported node in the tree is the heath hen clade, with NJ bootstrap/Bayesian support values listed above the branch. Bootstrap and Bayesian support values for all other nodes were less than $50 \%$. 
Table 1 Measures of molecular diversity for each population examined. For the greater prairie chicken, populations were both combined and considered separately. The sample size $(n)$, the number of haplotypes $(\mathrm{H})$, the haplotype diversity $(h)$, the mean number of pairwise differences between all pairs of haplotypes $(\pi)$ and the nucleotide diversity $\left(\pi_{n}\right)$ are given

\begin{tabular}{lrrlll}
\hline Taxon or population & $n$ & $\mathrm{H}$ & $h$ & $\pi$ & $\pi_{n}$ \\
\hline Attwater's prairie chicken & 8 & 5 & 0.786 & 1.650 & 0.003 \\
Greater prairie chicken & 80 & 36 & 0.932 & 5.108 & 0.011 \\
$\quad$ Colorado & 1 & 1 & NA & NA & NA \\
Kansas & 13 & 9 & 0.910 & 3.658 & 0.008 \\
$\quad$ Minnesota & 19 & 8 & 0.807 & 2.926 & 0.006 \\
Missouri & 12 & 8 & 0.924 & 5.261 & 0.011 \\
North Dakota & 11 & 8 & 0.891 & 4.341 & 0.010 \\
Oklahoma & 3 & 3 & 1.000 & 7.920 & 0.016 \\
$\quad$ Wisconsin & 21 & 9 & 0.862 & 6.158 & 0.014 \\
Heath hen & 18 & 8 & 0.745 & 3.686 & 0.008 \\
Lesser prairie chicken & 4 & 3 & 0.833 & 7.036 & 0.015 \\
Sharp-tailed grouse & 7 & 5 & 0.857 & 3.322 & 0.007 \\
\hline
\end{tabular}

Measures of molecular diversity shown in Table 1 reveal that the heath hen and Attwater's prairie chicken populations have lower values for $h, \pi$ and $\pi_{n}$ than the pooled sample of greater prairie chickens. In all cases, the sample of Attwater's prairie chickens had the lowest values for $h$, $\pi$ and $\pi_{n}$.

\section{Discussion}

Of the prairie grouse species and subspecies examined, the heath hen appears to be the most genetically distinct based on mtDNA sequences. With the exception of two samples, all heath hens group into a cluster of six haplotypes that are at least five steps from the nearest greater prairie chicken haplotype. The two samples that lie outside this group (MV3 and MV4 with haplotypes 2 and 14, respectively) may not be true heath hens. These samples were from hunted birds that had been mounted together, held in a private collection, and donated to the Martha's Vineyard Museum without collection information. We initially assumed that these birds had been hunted on Martha's Vineyard, but it is possible that they were brought from the Midwest, either as mounted skins or as live birds collected after release. Due to the poor condition of these skins and the postures in which they were mounted, a morphological determination of whether they were heath hens or greater prairie chickens was not possible. If these two samples are not true heath hens, then the heath hens in this study form a diagnosable, well-supported monophyletic mtDNA clade. This contrasts with the other species and subspecies in the analysis, including the endangered Attwater's prairie chicken, which are scattered throughout the network and the haplotype tree.
Given the high degree of morphological similarity between heath hens and greater prairie chickens (Gross 1928), what could account for the large amount of genetic divergence? There are two possibilities. First, heath hens of the East might have been geographically isolated from greater prairie chickens of the Midwest for a relatively long period of time and diverged genetically while remaining morphologically similar. In this scenario, heath hens would possess diagnosable genetic characters and, according to proponents of the Phylogenetic Species Concept (e.g. Vogler \& DeSalle 1994; Barrowclough \& Flesness 1996; Amato et al. 1998; Cracraft et al. 1998; Goldstein et al. 2000), would represent a distinct evolutionarily significant unit (ESU). Thus, it would not generally be appropriate to consider greater prairie chickens as a taxonomic equivalent suitable for introduction. However, for proponents of ESU concepts that consider the importance of the adaptive process (e.g. Waples 1991; Crandall et al. 2000), whether greater prairie chickens might still be considered as an ecological equivalent to the heath hen is an open question in need of further study.

For the second possible explanation, it is important to highlight that all our heath hen samples possessing collection information were collected on Martha's Vineyard after the mainland population had been extirpated. The isolation of the Martha's Vineyard population and the extreme bottleneck experienced by this population may make it appear more genetically distinct than the mainland heath hen population truly was. There were fewer than 100 heath hens on Martha's Vineyard from 1896 to 1908 (Gross 1928). Therefore, the genetic distinctiveness of the heath hen revealed by this study might reflect the results of human disturbance and sampling bias rather than the effects of evolutionary history.

An example of how anthropogenic disturbance can influence phylogenetic diagnosability was uncovered by Goldstein \& DeSalle (2003) in an examination of mtDNA diversity in extant vs. extinct populations of the threatened northeastern beach tiger beetle (Cicindela dorsalis dorsalis). From extant populations sampled, an isolated population from Martha's Vineyard was found to be diagnosable from all others by a single bp substitution (Vogler \& Desalle 1993). Strictly speaking, this population would therefore constitute a phylogenetic species. However, the subsequent examination of museum specimens from the Martha's Vineyard population and from now-extinct mainland populations revealed that the single diagnostic site was once widespread and that the Martha's Vineyard population was once polymorphic at this site (Goldstein \& DeSalle 2003). Therefore, the effects of human disturbance - the extinction of many mainland populations and the reduced population size on Martha's Vineyard - made this population appear more genetically distinct than it once was.

While the genetic differences we have uncovered between heath hens and greater prairie chickens (at least six mutational 
differences per $480 \mathrm{bp}$ ) are more substantial than those found by Vogler \& DeSalle (1993) for the Martha's Vineyard tiger beetle population (one mutational difference per 656 $\mathrm{bp}$ ), it is possible that our results reflect, at least in part, the impact of human disturbance. The low values of molecular diversity shown by the heath hen compared to the greater prairie chicken (Table 1) suggest that a demographic bottleneck probably reduced genetic diversity in this population. In addition, if samples MV3 and MV4 are indeed true heath hens and not imported greater prairie chickens, it would indicate that the heath hen was not monophyletic.

Another possibility that should be considered is that, due to a greater degree of isolation, the island population of heath hens was always more distinct from Midwestern greater prairie chickens than was the mainland population. Unfortunately, the lack of mainland heath hens in museum collections prevents us from knowing the true extent of the heath hen's original genetic diversity.

Our study confirms the findings of previous mtDNA analyses (Ellsworth et al. 1994, 1995, 1996) that T. cupido, T. pallidicinctus and T. phasianellus, while possessing significant morphological and behavioural differences, do not represent monophyletic mitochondrial lineages. This result either points to a recent divergence among these species or to the signature of historical and/or ongoing hybridization. This scenario is even more intriguing given that the heath hen, which showed minimal morphological and behavioural differentiation from the Midwestern greater prairie chicken and was probably geographically isolated more recently than the initial divergence of T. cupido, T. pallidicinctus and T. phasianellus, does appear to represent a monophyletic clade based on our data. In this context, either the heath hen appears monophyletic due to bias in our sampling but truly was not (as described above), or geneflow between $T$. cupido, T. pallidicinctus and T. phasianellus has resulted in mtDNA introgression among these species in areas of historical and current sympatry, and the heath hen, having been geographically isolated from all other prairie grouse populations, did not participate in this exchange of genes.

Although hybridization between T. cupido and both T. pallidicinctus (Bain \& Farley 2002) and T. phaisianellus (Evans 1966; Johnsgard \& Wood 1968) are known to occur, Ellsworth et al. 1994) reject this explanation to account for the lack of mtDNA coalescence in these species in favour of a scenario of recent divergence, possibly during the late Pleistocene, and incomplete lineage sorting. They argue that the strong morphological and behavioural differences observable between these species are probably due to rapid evolution as a result of sexual selection and adaptation to different regional environments. If incomplete lineage sorting is the cause of mtDNA polyphyly among Tympanuchus species, then we must seriously consider the effects of sampling on the results described here, because morphological and behavioural data indicate that heath hens diverged from greater prairie chickens after the divergence of T. cupido, T. pallidicinctus and T. phasianellus. Alternatively, the results of this study provide a reason to consider the possibility that hybridization and introgression have occurred with sufficient frequency to leave their mark on the mtDNA genealogy of Midwestern and Western Tympanuchus populations, while leaving the mtDNA of the geographically isolated heath hen alone to coalesce, uninterrupted, to monophyly.

It is also important to note that the Attwater's prairie chicken, a critically endangered subspecies that is currently being managed as an ESU, does not represent a phylogenetically distinguishable group based on mtDNA haplotypes. The small size of the Attwater's population is reflected in its low levels of genetic diversity (Table 1). Low genetic diversity has been associated with decreased population fitness in a small, isolated population of greater prairie chickens in Illinois (Bouzat et al. 1998; Westemeier et al. 1998). Therefore, if substantial habitat can be restored to support a viable population of prairie chickens on the Texas Gulf Coast, introducing greater prairie chickens from a genetically diverse source might serve to improve this population's prospects for survival, provided that relocated individuals are able to survive and reproduce successfully in their new environment. Similarly, small, fragmented greater prairie chicken populations, such as those in Wisconsin (see Bellinger et al. 2003; Johnson et al. 2003), might benefit from supplementation efforts focused on increasing numbers and genetic diversity. If a plan to introduce greater prairie chickens to Martha's Vineyard is to be formulated, it too must consider the ability of relocated birds to thrive in the available habitat and attempt to maximize genetic diversity, as any introduced population will begin small.

\section{Conclusions}

This study highlights the many complications that may be encountered when attempting to assess evolutionary distinctiveness, especially for extinct populations. Based on phylogenetic criteria and the mtDNA sequence data presented here, one might conclude that the Martha's Vineyard population of heath hens is an ESU because it has unique mtDNA character states not shared by other Tympanuchus populations. Does this mean that importing greater prairie chickens to Martha's Vineyard should be discounted as a possible conservation strategy? While the degree of differentiation we have uncovered suggests that historical isolation probably played some role in the genetic divergence of the heath hen from the greater prairie chicken, it is important to consider that island populations are often genetically distinct from their mainland counterparts and that human disturbance has probably impacted the genealogy of the heath hen. Therefore, our ability to sample only the isolated 
Martha's Vineyard population may make the heath hen appear more genetically distinct than the pre-European population, as a whole, truly was. In addition, any management action depends on a clear articulation of the conservation goals for the Martha's Vineyard environment. The phylogenetic guidelines for designating ESUs are important, but by themselves are inadequate, for situations where a population is extinct and ecological restoration is the conservation goal to be achieved. Criteria that consider adaptation and ecological exchangeability are important to consider in such situations. A better understanding of the ecological role of prairie grouse, focusing on ecological adaptations to different habitat types, should help provide the additional information necessary to inform managers if introduced greater prairie chickens are likely to survive and reproduce in the restored heathland habitat of Martha's Vineyard. If so, they might serve as a valuable indicator of ecosystem integrity for this unique environment.

\section{Acknowledgements}

We would like to thank Douglas Causey (Museum of Comparative Zoology), Kristof Zyskowski (Yale Peabody Museum), Philip Sudman (Tarleton State University), Jill Bouck (Martha's Vineyard Museum), Jack Cully and Mayee Wong (Kansas Cooperative Fish and Wildlife Research Unit), and Mark Robbins (University of Kansas Museum of Natural History) for their invaluable assistance obtaining samples. Thanks also to Michael Russello, Catherine Burns, Bob Wayne, and two anonymous reviewers for comments that helped improve the manuscript. This research was supported by YIBS Ecosave funds to A.C. and was part of Prairie Chickens \& Grasslands: 2000 and Beyond, a research project sponsored by the Society of Tympanuchus Cupido Pinnatus, Ltd.

\section{References}

Amato G, Gatesy J, Brazaitis P (1998) PCR assays of variable nucleotide sites for identification of conservation units. In: Molecular Approaches to Ecology and Evolution: an Example from Caiman (eds DeSalle R, Schierwater B), pp. 177-180. Birkhauser, Basel.

Bain MR, Farley GH (2002) Display by apparent hybrid prairiechickens in a zone of geographic overlap. Condor, 104, 683-687.

Baker AJ, Marshall HD (1997) Mitochondrial control region sequences as tools for understanding evolution. In: Avian Molecular Evolution and Systematics (ed. Mindell DP), pp. 51-83. Academic Press, San Diego.

Barrowclough GF, Flesness NR (1996) Species, subspecies, and races: the problem of units of management in conservation. In: Wild Mammals in Captivity (eds Keiman GC, Allen M, Harris H), pp. 247-254. University of Chicago Press, Chicago.

Bellinger MR, Johnson JA, Toepfer J, Dunn P (2003) Loss of genetic variation in greater prairie chickens following a population bottleneck in Wisconsin, U.S.A. Conservation Biology, 17, 717724.

Bouzat J, Cheng HH, Harris AL et al. (1998) Genetic evaluation of a demographic bottleneck in the greater prairie chicken. Conservation Biology, 12, 836-843.

Brewster W (1885) The heath hen of Massachusetts. Auk, 2, 80-84.
Clement M, Posada D, Crandall KA (2000) TCs: a computer program to estimate gene genealogies. Molecular Ecology, 9, 1657-1659.

Cokinos C (2000) Hope is the Thing with Feathers: A Personal Chronicle of Vanished Birds. J.P. Tarcher/Putnam, New York.

Cooper A (1994) DNA from museum specimens. In: Ancient DNA (eds Herrmann B, Hummel S), pp. 149-165. Springer, New York.

Cracraft J, Feinstein J, Helm-Bychowski C (1998) Sorting out tigers (Panthera tigris): mitochondrial sequences, nuclear inserts, systematics, and conservation genetics. Animal Conservation, 1, 139-150.

Crandall KA, Bininda-Edmonds ORP, Mace GM, Wayne RK (2000) Considering evolutionary processes in conservation biology. Trends in Ecology and Evolution, 17, 390-395.

Crandall KA, Templeton AR (1993) Empirical tests of some predictions from coalescent theory with applications to intraspecific phylogeny reconstruction. Genetics, 134, 959-969.

Desjardins P, Morais R (1990) Sequence and gene organization of the chicken mitochondrial genome: a novel gene order in higher vertebrates. Journal of Molecular Biology, 212, 599-634.

Droge S (1998) Birds and landscape changes in northeastern forests. In: Status and Trends of the Nation's Biology Resources (eds Mac MJ, Opler O, Haecker C, Dorin P), pp. 187-189. US Department of the Interior, USGS, Washington, DC.

Drovetski SV (2002) Molecular phylogeny of grouse: Individual and combined performance of W-linked, autosomal, and mitochondrial loci. Systematic Biology, 51, 930-945.

Ellsworth DL, Honeycut RL, Silvy NJ (1995) Phylogenetic relationships among North American grouse inferred from restriction endonuclease analysis of mitochondrial DNA. Condor, 97, 492502.

Ellsworth DL, Honeycut RL, Silvy NJ (1996) Systematics of grouse and ptarmigan determined by nucleotide sequences of the mitochondrial cytochrome- $b$ gene. $A u k, 113,811-822$.

Ellsworth DL, Honeycut RL, Silvy NJ, Rittenhouse KD, Smith MH (1994) Mitochondrial-DNA and nuclear-gene differentiation in North American prairie grouse (genus Tympanuchus). Auk, 111, 661-671.

Evans K (1966) Observations on a hybrid between the sharp-tailed grouse and the greater prairie-chicken. Auk, 83, 128-129.

Forbush EH (1927) Birds of Massachusetts and Other New England States. Norwood Press, Norwood, MA.

Foster DR, Motzkin G (1999) Historical Influences on the Landscape of Martha's Vineyard - Perspectives on the Management of Manuel F. Correllus State Forest. Harvard Forest Paper no. 23. Harvard Forest, Petersham, MA.

Fuhlendorf SD, Woodward AJW, Leslie DM, Jr Shackford JS (2002) Multi-scale effects of habitat loss and fragmentation on lesser prairie-chicken populations of the US Southern Great Plains. Landscape Ecology, 17, 617-628.

Goldstein PZ, DeSalle R (2003) Calibrating phylogenetic species formation in a threatened insect using DNA from historical specimens. Molecular Ecology, 12, 1993-1998.

Goldstein PZ, DeSalle R, Amato G, Vogler AP (2000) Conservation genetics at the species boundary. Conservation Biology, 14, 120131.

Gross AO (1928) Heath Hen. Memoirs of the Boston Society of Natural History, 6, 4. Boston Society of Natural History, Boston.

Huelsenbeck JP, Ronquist F (2001) MRBAYEs: Bayesian inference of phylogeny. Bioinformatics, 17, 754-755.

IUCN (1995) Guidelines for Re-Introductions. Annex 6 to the Minutes of the 41st Meeting of the Council. World Conservation Union (IUCN), Gland, Switzerland. 
Johnsgard PA (1983) The Grouse of the World. University of Nebraska Press, Lincoln, NE.

Johnsgard PA, Wood RE (1968) Distributional changes and interactions between prairie chickens and sharp-tailed grouse in the Midwest. Wilson Bulletin, 80, 173-188.

Johnson JA, Toepfer JE, Dunn PO (2003) Contrasting patterns of mitochondrial and microsatellite population structure in fragmented populations of greater prairie-chickens. Molecular Ecology, 12, 3335-3347.

Landweber LF (1999) Something old for something new: the future of ancient DNA in conservation biology. In: Genetics and the Extinction of Species (eds Landweber LF, Dobson AP), pp. 163-186. Princeton University Press, Princeton, NJ.

Lucchini V, Höglund J, Klaus S, Swenson J, Randi E (2001) Historical biogeography and a mitochondrial DNA phylogeny of grouse and ptarmigan. Molecular Phylogenetics and Evolution, 20, 149-162.

Motzkin G, Foster DR (2002) Grasslands, heathlands and shrublands in coastal New England: historical interpretations and approaches to conservation. Journal of Biogeography, 29, 1569-1590.

Mundy NI, Unitt P, Woodruff DS (1997) Skin from feet of museum specimens as a non-destructive source of DNA for avian genotyping. Auk, 114, 126-129.

Posada D, Crandall KA (2001) Intraspecific gene genealogies: trees grafting into networks. Trends in Ecology and Evolution, 16, 3745.

Posada D, Crandall KA (1998) Modeltest: testing the model of DNA substitution. Bioinformatics, 14, 817-818.

Pyne SJ (1982) Fire in America. Princeton University Press, Princeton, NJ.

Saitou N, Nei M (1987) The neighbor-joining method: a new method for reconstructing phylogenetic trees. Molecular Biology and Evolution, 4, 406-425.

Schneider S, Roessli D, Excoffier L (2000) ARLEQUIN, Version 2.000: a Software for Population Genetics Data Analysis. Genetics and Biometry Laboratory, University of Geneva, Switzerland.

Seddon PJ, Soorae PS (1999) Guidelines for subspecific substitutions in wildlife restoration projects. Conservation Biology, 13, 177-184.

Silvy NJ, Griffin CP, Lockwood MA, Morrow ME, Peterson MJ (1999) The Attwater's prairie chicken - a lesson in conservation biology research. In: The Greater Prairie Chicken a National Look (eds Svedarsky WD, Hier RH, Silvy NJ), pp. 153-162. Miscellaneous Publication 99-1999. Minnesota Agricultural Experiment Station, University of Minnesota, Saint Paul, MN.

Svedarsky WD, Westemeier RL, Robel RJ, Gough S, Toepfer JE (2000) Status and management of the greater prairie-chicken
Tympanuchus cupido pinnatus. North America. Wildlife Biology, 6, 277-284.

Swofford DL (2000) PAUP*. Phylogenetic Analysis Using Parsimony (* and Other Methods), Version 4. Sinauer Associates Inc, Sunderland, MA.

Tamura K, Nei M (1993) Estimation of the number of nucleotide substitutions in the control region of mitochondrial DNA in humans and chimpanzees. Molecular Biology and Evolution, 10, 512-526.

Thompson JD, Gibson TJ, Plewniak F, Jeanmougin F, Higgins DG (1997) The Clustal X windows interface: flexible strategies for multiple sequence alignment aided by quality analysis tools. Nucleic Acids Research, 24, 4876-4882.

Vogler AP, DeSalle R (1993) Phylogeograpic patterns in coastal North American tiger beetles (Cicindela dorsalis Say) inferred from mitochondrial DNA sequences. Evolution, 47, 1192-1202.

Vogler AP, DeSalle R (1994) Diagnosing units of conservation management. Conservation Biology, 6, 170-178.

Waples RS (1991) Pacific salmon, Oncorhynchus spp. and the definition of 'species' under the Endangered Species Act. Marine Fisheries Review, 53, 11-22.

Westemeier RL, Brawn JD, Simpson SA et al. (1998) Tracking the long-term decline and recovery of an isolated population. Science, 282, 1695-1698.

Eric Palkovacs is a Ph.D. student interested in the applications of molecular genetic techniques to questions of ecology, biogeography and conservation. Adam Oppenheimer participated in this project as his undergraduate thesis. Eugene Gladyshev is a $\mathrm{Ph}$.D. student interested in population genetics and conservation. John Toepfer heads the research program of the Society of Tympanuchus Cupido Pinnatus, a nonprofit society dedicated to the preservation of greater prairie chickens. George Amato is the Director of Conservation and Science at the Wildlife Conservation Society, with research interests primarily concerned with conservation genetics of species in highly fragmented environments and the interface of ex situ and in situ conservation management strategies. Tom Chase is Director of Eastern Massachusetts Programs for The Nature Conservacy, with focal interests in ecological restoration, restoration research and the development of innovative conservation strategies. Gisella Caccone heads the YIBS Molecular Systematics and Conservation Genetics Laboratory and works on a variety of evolutionary genetic problems including island biogeography, population genetics of mosquitoes, and conservation genetics of giant tortoises. 
1768 E. P. PALKOVACS ET AL.

\section{Appendix I}

Samples included in this analysis

\begin{tabular}{|c|c|c|c|c|}
\hline Sample ID & Taxon & Population origin & Haplotype & Sample origin \\
\hline A451 & Attwater's prairie chicken & Texas (TX) & 1 & Fossil Rim Wildlife Center, Texas \\
\hline AF532432 & Attwater's prairie chicken & Texas (TX) & 2 & Drovetski (2002) \\
\hline $99-86$ & Attwater's prairie chicken & Texas (TX) & 11 & Houston Zoo, Texas \\
\hline A391 & Attwater's prairie chicken & Texas (TX) & 17 & Fossil Rim Wildlife Center, Texas \\
\hline A182 & Attwater's prairie chicken & Texas (TX) & 18 & Fossil Rim Wildlife Center, Texas \\
\hline A393 & Attwater's prairie chicken & Texas (TX) & 18 & Fossil Rim Wildlife Center, Texas \\
\hline A409 & Attwater's prairie chicken & Texas (TX) & 18 & Fossil Rim Wildlife Center, Texas \\
\hline $\mathrm{A} 427$ & Attwater's prairie chicken & Texas (TX) & 18 & Fossil Rim Wildlife Center, Texas \\
\hline AF532430 & Greater prairie chicken & Colorado (CO) & 1 & Drovetski (2002) \\
\hline AN1 & Greater prairie chicken & Kansas (KS) & 2 & Wild \\
\hline WAB123 & Greater prairie chicken & Kansas (KS) & 8 & Wild \\
\hline C3143 & Greater prairie chicken & Kansas (KS) & 11 & Wild \\
\hline PL & Greater prairie chicken & Kansas (KS) & 11 & Wild \\
\hline $\mathrm{CH} 2$ & Greater prairie chicken & Kansas (KS) & 13 & Wild \\
\hline C3115 & Greater prairie chicken & Kansas (KS) & 15 & Wild \\
\hline AN2 & Greater prairie chicken & Kansas (KS) & 19 & Wild \\
\hline VALMORT & Greater prairie chicken & Kansas (KS) & 22 & Wild \\
\hline WAB119 & Greater prairie chicken & Kansas (KS) & 22 & Wild \\
\hline $\mathrm{CH} 3$ & Greater prairie chicken & Kansas (KS) & 22 & Wild \\
\hline K2MORT & Greater prairie chicken & Kansas (KS) & 22 & Wild \\
\hline C3117 & Greater prairie chicken & Kansas (KS) & 30 & Wild \\
\hline AF532431 & Greater prairie chicken & Kansas (KS) & 34 & Drovetski (2002) \\
\hline E9495 & Greater prairie chicken & Minnesota (MN) & 2 & Wild \\
\hline MN264328 & Greater prairie chicken & Minnesota (MN) & 2 & Wild \\
\hline MN343 & Greater prairie chicken & Minnesota (MN) & 6 & Wild \\
\hline MN H348 & Greater prairie chicken & Minnesota (MN) & 7 & Wild \\
\hline C 341 & Greater prairie chicken & Minnesota (MN) & 12 & Wild \\
\hline MN284751 & Greater prairie chicken & Minnesota (MN) & 20 & Wild \\
\hline MN284 & Greater prairie chicken & Minnesota (MN) & 20 & Wild \\
\hline MN284168 & Greater prairie chicken & Minnesota (MN) & 20 & Wild \\
\hline MN284420 & Greater prairie chicken & Minnesota (MN) & 21 & Wild \\
\hline MN356 & Greater prairie chicken & Minnesota (MN) & 21 & Wild \\
\hline C148162 & Greater prairie chicken & Minnesota (MN) & 22 & Wild \\
\hline MN284419 & Greater prairie chicken & Minnesota (MN) & 22 & Wild \\
\hline MN284703 & Greater prairie chicken & Minnesota (MN) & 22 & Wild \\
\hline MN284704 & Greater prairie chicken & Minnesota (MN) & 22 & Wild \\
\hline MN284798 & Greater prairie chicken & Minnesota (MN) & 22 & Wild \\
\hline MN284799 & Greater prairie chicken & Minnesota (MN) & 22 & Wild \\
\hline MN283169 & Greater prairie chicken & Minnesota (MN) & 22 & Wild \\
\hline MN284346 & Greater prairie chicken & Minnesota (MN) & 22 & Wild \\
\hline MN355 & Greater prairie chicken & Minnesota (MN) & 28 & Wild \\
\hline M25 & Greater prairie chicken & Missouri (MO) & 2 & Wild \\
\hline M26 & Greater prairie chicken & Missouri (MO) & 2 & Wild \\
\hline M28 & Greater prairie chicken & Missouri (MO) & 2 & Wild \\
\hline M33 & Greater prairie chicken & Missouri (MO) & 3 & Wild \\
\hline M10 & Greater prairie chicken & Missouri (MO) & 23 & Wild \\
\hline M27 & Greater prairie chicken & Missouri (MO) & 23 & Wild \\
\hline M4 & Greater prairie chicken & Missouri (MO) & 24 & Wild \\
\hline M11 & Greater prairie chicken & Missouri (MO) & 25 & Wild \\
\hline M30 & Greater prairie chicken & Missouri (MO) & 25 & Wild \\
\hline M32 & Greater prairie chicken & Missouri (MO) & 31 & Wild \\
\hline M24 & Greater prairie chicken & Missouri (MO) & 33 & Wild \\
\hline M22 & Greater prairie chicken & Missouri (MO) & 38 & Wild \\
\hline ND283607 & Greater prairie chicken & North Dakota (ND) & 1 & Wild \\
\hline ND149253 & Greater prairie chicken & North Dakota (ND) & 2 & Wild \\
\hline ND284706 & Greater prairie chicken & North Dakota (ND) & 2 & Wild \\
\hline ND293669 & Greater prairie chicken & North Dakota (ND) & 2 & Wild \\
\hline ND283669 & Greater prairie chicken & North Dakota (ND) & 2 & Wild \\
\hline ND283249 & Greater prairie chicken & North Dakota (ND) & 5 & Wild \\
\hline
\end{tabular}


MTDNA ANALYSIS OF THE EXTINCT HEATH HEN 1769

Appendix I Continued

\begin{tabular}{|c|c|c|c|c|}
\hline Sample ID & Taxon & Population origin & Haplotype & Sample origin \\
\hline ND284229 & Greater prairie chicken & North Dakota (ND) & 9 & Wild \\
\hline ND284705 & Greater prairie chicken & North Dakota (ND) & 29 & Wild \\
\hline ND284052 & Greater prairie chicken & North Dakota (ND) & 32 & Wild \\
\hline ND284297 & Greater prairie chicken & North Dakota (ND) & 36 & Wild \\
\hline ND283244 & Greater prairie chicken & North Dakota (ND) & 37 & Wild \\
\hline OK125 & Greater prairie chicken & Oklahoma (OK) & 11 & Wild \\
\hline OK72 & Greater prairie chicken & Oklahoma (OK) & 25 & Wild \\
\hline OK153 & Greater prairie chicken & Oklahoma (OK) & 37 & Wild \\
\hline WS284321 & Greater prairie chicken & Wisconsin (WI) & 2 & Wild \\
\hline WS284323 & Greater prairie chicken & Wisconsin (WI) & 2 & Wild \\
\hline WS284806 & Greater prairie chicken & Wisconsin $(\mathrm{WI})$ & 2 & Wild \\
\hline WS283285 & Greater prairie chicken & Wisconsin (WI) & 2 & Wild \\
\hline WS284105 & Greater prairie chicken & Wisconsin (WI) & 2 & Wild \\
\hline WS284822 & Greater prairie chicken & Wisconsin (WI) & 4 & Wild \\
\hline WSOR351P & Greater prairie chicken & Wisconsin (WI) & 4 & Wild \\
\hline WSOR357P & Greater prairie chicken & Wisconsin (WI) & 22 & Wild \\
\hline WS283278 & Greater prairie chicken & Wisconsin $(\mathrm{WI})$ & 26 & Wild \\
\hline WS283279 & Greater prairie chicken & Wisconsin (WI) & 26 & Wild \\
\hline WS284136 & Greater prairie chicken & Wisconsin $(\mathrm{WI})$ & 26 & Wild \\
\hline WS284215 & Greater prairie chicken & Wisconsin (WI) & 27 & Wild \\
\hline WS284750 & Greater prairie chicken & Wisconsin (WI) & 40 & Wild \\
\hline WS284776 & Greater prairie chicken & Wisconsin $(\mathrm{WI})$ & 40 & Wild \\
\hline WS284819 & Greater prairie chicken & Wisconsin (WI) & 40 & Wild \\
\hline WS284820 & Greater prairie chicken & Wisconsin (WI) & 40 & Wild \\
\hline WS284131 & Greater prairie chicken & Wisconsin (WI) & 40 & Wild \\
\hline WS284192 & Greater prairie chicken & Wisconsin (WI) & 40 & Wild \\
\hline WS284207 & Greater prairie chicken & Wisconsin (WI) & 43 & Wild \\
\hline WS289137 & Greater prairie chicken & Wisconsin $(\mathrm{WI})$ & 44 & Wild \\
\hline WS284287 & Greater prairie chicken & Wisconsin (WI) & 45 & Wild \\
\hline MV3 & Heath hen & No collection information & 2 & Martha's Vineyard Museum \\
\hline MV4 & Heath hen & No collection information & 14 & Martha's Vineyard Museum \\
\hline MV1 & Heath hen & No collection information & 46 & Martha's Vineyard Museum \\
\hline MV2 & Heath hen & No collection information & 46 & Martha's Vineyard Museum \\
\hline MV5 & Heath hen & No collection information & 46 & Felix Neck, Martha's Vineyard \\
\hline YPM 69503 & Heath hen & Martha's Vineyard & 47 & Yale Peabody Museum \\
\hline YPM 69502 & Heath hen & Martha's Vineyard & 50 & Yale Peabody Museum \\
\hline MCZ 297274 & Heath hen & Martha's Vineyard (1889) & 48 & Museum of Comparative Zoology \\
\hline MCZ 246053 & Heath hen & Martha's Vineyard (1890) & 46 & Museum of Comparative Zoology \\
\hline MCZ 181418 & Heath hen & Martha's Vineyard (1896) & 46 & Museum of Comparative Zoology \\
\hline MCZ 181417 & Heath hen & Martha's Vineyard (1896) & 46 & Museum of Comparative Zoology \\
\hline MCZ 181423 & Heath hen & Martha's Vineyard (1896) & 46 & Museum of Comparative Zoology \\
\hline MCZ 181419 & Heath hen & Martha's Vineyard (1896) & 48 & Museum of Comparative Zoology \\
\hline MCZ 181425 & Heath hen & Martha's Vineyard (1896) & 48 & Museum of Comparative Zoology \\
\hline MCZ 301010 & Heath hen & Martha's Vineyard (1899) & 51 & Museum of Comparative Zoology \\
\hline MCZ 187180 & Heath hen & Martha's Vineyard (1903) & 49 & Museum of Comparative Zoology \\
\hline MCZ 297275 & Heath hen & Martha's Vineyard (1909) & 46 & Museum of Comparative Zoology \\
\hline MCZ 297272 & Heath hen & Martha's Vineyard (1912) & 46 & Museum of Comparative Zoology \\
\hline AJ297175 & Lesser prairie chicken & Unknown & 41 & Lucchini et al. (2001) \\
\hline AJ297174 & Lesser prairie chicken & Unknown & 41 & Lucchini et al. (2001) \\
\hline AF532433 & Lesser prairie chicken & Kansas (KS) & 35 & Drovetski (2002) \\
\hline AF532434 & Lesser prairie chicken & Kansas (KS) & 39 & Drovetski (2002) \\
\hline AF532435 & Sharp-tailed grouse & Idaho (ID) & 1 & Drovetski (2002) \\
\hline ND284339ST & Sharp-tailed grouse & North Dakota (ND) & 1 & Wild \\
\hline ND327ST & Sharp-tailed grouse & North Dakota (ND) & 1 & Wild \\
\hline ND368ST & Sharp-tailed grouse & North Dakota (ND) & 2 & Wild \\
\hline NDYW85ST & Sharp-tailed grouse & North Dakota (ND) & 16 & Wild \\
\hline ND284334ST & Sharp-tailed grouse & North Dakota (ND) & 42 & Wild \\
\hline AF532436 & Sharp-tailed grouse & Washington (WA) & 10 & Drovetski (2002) \\
\hline AF532426 & Dendragopus obscurus & Utah (UT) & Outgroup & Drovetski (2002) \\
\hline AF532427 & Dendragopus obscurus & Washington (WA) & Outgroup & Drovetski (2002) \\
\hline
\end{tabular}

